\title{
Streptomyces as Overexpression System for Heterologous Production of an Antimicrobial Peptide
}

\author{
Marisol Roldán-Tapia ${ }^{\mathrm{a}}$, Jozef Anné ${ }^{\mathrm{b}}$, Ana Gisela Reyes ${ }^{\mathrm{c}}$, Ulises Carrasco ${ }^{2 \mathrm{a}}$, Cesar Millán-Pacheco ${ }^{\mathrm{d}}$, \\ Javier Barrios-González ${ }^{3 a}$ and Armando Mejía ${ }^{* a}$
}

${ }^{a}$ Department of Biotechnology, Universidad Autónoma Metropolitana-Iztapalapa, México DF, México, San Rafael
Atlixco 186. Col. Vicentina. C.P 09340; ${ }^{b}$ Rega Institute, Katholieke Universiteit Leuven, Laboratory of Molecular
Bacteriology, Minderbroedersstraat 10,B-3000 Leuven, Belgium; ${ }^{c}$ Conacyt-CIBNOR, Centro de Investigaciones
Biológicas del Noroeste, La Paz, BCS, México; ${ }^{d}$ Facultad de Farmacia, Universidad Autónoma del Estado de Morelos,
Avenida Universidad 1001, CP 62209, Cuernavaca, Morelos, México

\begin{abstract}
Defense mechanisms of plants against phytopathogens include cationic antimicrobial peptides (CAPs). The broad-spectrum activity of these peptides has been evaluated previously against different phytopathogens. Their lack of toxicity for plants and animals is a promising feature for pest control. Although, some attempts have been made previously in order to increase their heterologous expressions, the employed strategies have so far proven to be ineffective. Low production yield and elevated costs are the obstacles to overcome. In this study, a strategy for CAP overexpression is presented based on the construction of an expression cassette for Streptomyces lividans TK24. This system contains elements that allow the increase of the efficiency of the peptide's expression. The main elements included in this cassette are the sequences of the promoter and signal peptide from a subtilisin inhibitor gene of Streptomyces venezuelae. This allows the efficient secretion of the peptide to the growth medium, thereby simplifying its recovery and avoiding its toxic effect on the producing organism. The results obtained demonstrate the system's efficiency by achieving a peptide concentration of $11.61 \mathrm{mg} / \mathrm{ml}$. This represents at least a 10-fold increase compared to previously established strategies.
\end{abstract}

A R T I C L E H I S T O R Y

Received: July 15,2016

Revised: November 29, 2016

Accepted: February 1, 2017

DOI: $10.2174 / 0929866524666170208$ 154327

Keywords: Heterologous production, antimicrobial peptide, Streptomyces lividans, secreted peptide.

\section{INTRODUCTION}

Recently, the importance of antimicrobial peptides in plant disease control has been widely recognized. They could be used in several fields of application, and large quantities of antimicrobial peptides would be required. However, their production is very expensive; this is why a suitable production method, alternative to traditional chemical synthesis is necessary.

Production of recombinant antimicrobial peptides in prokaryotic systems has demonstrated the viability of this approach. Nevertheless, expression of antimicrobial peptides in Escherichia coli is potentially limited due to their toxicity to host cells and susceptibility to proteolytic degradation, although this can be reduced using a fusion protein approach [1]. As an alternative, we describe a successful antimicrobial peptide production system in S. lividans which showed to be

*Address correspondence to this author at Department of Biotechnology, Universidad Autónoma Metropolitana San Rafael Atlixco 186, Vicentina, Iztapalapa., P.O. Box: 09340. Ciudad de México, México;

Tel: ++52(55)58046438; Fax: +52(55)58044712;

E-mail: ama@xanum.uam.mx effective for the secretion of large quantities of cationic antimicrobial peptides.

Antimicrobial peptides, particularly those of the cationic type (CAPs), affect the plasma membrane of the target organism by inducing both destabilization and stress [2]. Mammalian cells are not affected by these peptides as their membranes contain cholesterol (up to $25 \%$ ), a predominance of phosphatidylcholine lipids, and an essentially neutral (zwitterionic) outer leaflet [3], which interfere with CAP activity. This selectivity can be exploited in many applications $[4,5]$. Additionally, there is a low probability that the exposed microorganisms will develop resistance against CAPs. Unfortunately, although they could be used in several fields of application, including agriculture, their production costs are elevated as the most effective approach so far is by chemical synthesis. In addition, there are heterologous expression strategies using Escherichia coli as host [6]. Examples of this approach include the production of cecropin [7, 8], moricin [9], human defensins [10], magainin [11, 12] and concatemers, such as buforin II. In some of these strategies, an attempt has been made to prevent CAP lethality by using recombinant protein technology in order to mask the peptide's intrinsic antimicrobial activity [13]. There are other 
systems, such as transgenic mouse erythrocytes for magainin production and recombinant hybrid production, such as the cecropin and magainin peptide in Pichia pastoris [14]. Unfortunately, these strategies have limitations such as low yield $[7,9]$ and proteolysis of the fusion protein that masks its toxic properties [15]. Additionally, when these strategies are employed, the cytoplasmic accumulation of the expressed proteins in the form of inclusion bodies is frequently observed [16], inducing activity inhibition and rendering the purification process difficult. Consequently, this is reflected in low yield values [17].

Therefore, as a solution to the difficulties for heterologous expression of CAP we demonstrate efficient production by Streptomyces lividans

\section{MATERIALS AND METHODS}

\subsection{Peptide Modelling and Simulations}

For the construction of the CAP, Glu was substituted by Ala at the 14th position of the original sequence (Phe-LysCys-Arg-Arg-Trp-Gln-Trp-Arg-Met-Lys-Lys-Leu-Glu-Ala). The initial model was built using iTasser server [18, 19]. The model was immersed in a cubic box of water TIP3P with a concentration of $\mathrm{KCl} 0.15 \mathrm{M}$ using charmm-gui web server (http://www.charmm-gui.org) [20]. All molecular dynamics simulations were performed using the GROMACS 5.0.5 [21, 22] software using charmm 36 parameters [23] with the gromacs inputs as suggested by charmm-gui server. The simulations were run by $100 \mathrm{~ns}$ at $37^{\circ} \mathrm{C}, 1 \mathrm{~atm}$ of pressure and periodic boundary conditions.

\subsection{Strains, Plasmids Constructions, Media and Growth Conditions}

The following phytopathogens were used in this research: Collectotrichum sp, Fusarium oxysporum, Fusarium solani, Nigrospora oryzae, Pseudomonas aureofaciens, Pseudomonas syringae pv. tomato, Ralstonia solanacearum, Xanthomonas axonopodis pv. Citri and Bacillus subtilis. All of them were $\mathrm{p}$ ded by Química Agronómica de México, S. de R.L. M.I $\_$ture media preparation were performed according to [24] and [25].

\subsection{DNA Manipulations}

Molecular biology techniques were performed according to [24] and [25]. Restriction endonucleases and DNA modifying enzymes were provided by Invitrogen and Promega. PCR reactions were carried out using the primers reported by Van Dessel, 2003 [28] employing the GoTaq Flexi DNA polymerase.

\subsection{CAP Selection}

The standard peptide was synthesized by Thermo Fisher Scientific de México (Invitrogen) with a $50 \%$ purity and it was stored at $-20^{\circ} \mathrm{C}$.

The selected CAP is a broad-spectrum cationic peptide that has been reported as non-toxic for plants and animals. Its activity was evaluated through serial dilutions $\left(1 \times 10^{-1}\right.$ to
Table 1. Strains and plasmids used.

\begin{tabular}{|c|c|c|}
\hline Strain & Genotype & Reference \\
\hline $\begin{array}{l}\text { Escherichia } \\
\text { coli DH5 } \alpha\end{array}$ & $\begin{array}{c}\text { F endA1 glnV44 thi-1 recA1 relA1 } \\
\text { gyrA96 } \\
\text { deoR nup } \Phi 80 \text { dlacZAM15 } \\
\begin{array}{c}\Delta(\operatorname{lacZYA}-\arg F) U 169, \text { hsdR17 }\left(r_{K}^{-}\right. \\
\left.m_{K}^{+}\right), \lambda-\end{array}\end{array}$ & $\begin{array}{c}\text { Grant, } 1990 \\
{[26]}\end{array}$ \\
\hline $\begin{array}{l}\text { Streptomyces } \\
\text { lividans TK24 }\end{array}$ & str-6 SLP2- SLP3- & $\begin{array}{c}\text { Kieser, } 2000 \\
\text { [27] }\end{array}$ \\
\hline Plasmid & Characteristics & Reference \\
\hline pIJ486b & $\begin{array}{l}\text { Vector from pIJ10, like pIJ } 487 \text { but } \\
\text { with opposite orientation of the } \\
\text { fragment } B g l I I \text { containing the clon- } \\
\text { ing sites. }\end{array}$ & $\begin{array}{c}\text { Kieser, } 2000 \\
\text { [27] }\end{array}$ \\
\hline
\end{tabular}

$1 \times 10^{-6}$ ) and performing bioassays on different pathogens by assessing optical density (OD) at $600 \mathrm{~nm}$ [29]. Liquid LB medium was used to culture these bacteria and the incubations were carried out at $37^{\circ} \mathrm{C}$. Results were expressed as the inhibition percentage of bacterial growth mediated by the peptide's activity (Figure $\mathbf{3}$ ).

\subsection{Design of Expression Cassette}

For the construction of the cassette, preferential codons were used for $S$. lividans with $\mathrm{G}$ and $\mathrm{C}$ at the third position [30]. The peptide of interest was fused to the vsi promoter and signal sequence ( $v s i-s s)$ of the subtilisin inhibitor from Streptomyces venezuelae CBS762.70, which is a signal peptide with a proven high secretion efficiency [31, 32]. The vsi promoter displays a superior transcription initiation of 1.5 and 1.9-fold compared to the aph and $e r m E p^{*}$ promoters, respectively [33].

The cloning vector used was pIJ486, which is derived from the pIJ101 plasmid including a transcription terminator sequence and a thiostrepton resistance marker.

\subsection{Minigene Amplification and Cloning in Streptomyces lividans TK24}

Based on the cassette designed in silico, the subcloned minigene was synthesized in the PIDT-smart vector which was amplified by transforming Escherichia coli DH5 $\alpha$ through electroporation. The fragment was digested using the Bam $\mathrm{H} 1$ and HindIII restriction enzymes and cloned into the pIJ486 vector to finally be used to transform protoplasts of S. lividans TK24 [24].

\subsection{S. lividans TK24 Protoplast Transformation}

Biomass was obtained from a $48 \mathrm{~h}$ preculture of $S$. lividans TK24 grown in YEME medium for $48 \mathrm{~h}$ and incubated at $30{ }^{\circ} \mathrm{C}$ and $150 \mathrm{rpm}$. A flask containing $250 \mathrm{ml}$ of S medium, was added $50 \mathrm{ml}$ of glucose solution $(66.6 \mathrm{mg} / \mathrm{ml})$ and $12.64 \mathrm{ml}$ of glycine $20 \%$. Then was inoculated with $5 \mathrm{ml}$ of fragmented mycelium, which was incubated at $30^{\circ} \mathrm{C}$ and 
$150 \mathrm{rpm}$ for $24 \mathrm{~h}$. Protoplasts were obtained using a technique previously described by Hopwood [24].

Four plates were prepared containing $\mathrm{R}_{2}$ medium described by Hopwood [24], supplemented with $\mathrm{CuSO}_{4} .5 \mathrm{H}_{2} \mathrm{O}$ (2mM-1/1000) and $\mathrm{CaCl}_{2} \cdot 2 \mathrm{H}_{2} \mathrm{O} 36.8 \%$ (1/100). $10 \mu \mathrm{l}$ of ligation mixture and $500 \mu \mathrm{l}$ of PEG6000 $35 \%$ (v/v) were added to a tube containing $200 \mu \mathrm{l}$ of a protoplast suspension (OD600 with a value close to 1). The protoplast suspension and ligation mixture were mixed and incubated at a room temperature $\left(30^{\circ} \mathrm{C}\right.$ ) for $24 \mathrm{~h}$. Each $\mathrm{R}_{2}$-plate was inoculated with $150 \mu \mathrm{l}$ of this transformation mixture. Plates were subsequently incubated at $30{ }^{\circ} \mathrm{C}$ for $24 \mathrm{~h}$ in order to allow protoplast regeneration. After this period, $50 \mu \mathrm{g} / \mathrm{ml}$ thiostrepton was added and dispersed within the plate. The transformants were allowed to grow for an additional $24 \mathrm{~h} \mathrm{[8].}$

\subsection{Transformant Selection by Colony PCR}

In order to verify that the expression cassette was present in the transformants, colonies were disrupted and their DNA taken as template. A PCR was performed using the conditions and primers reported by Van Dessel, 2003 [28] PCR results were corroborated by automated sequencing. Bioassays were carried out to verify the production of the peptide and its secretion to the growth medium.

\subsection{Activity Assays on Bacteria}

To rule out that the observed activity originated from a secondary metabolite from $S$ lividans but not the peptide, an ultrafiltration step was performed. Biomass was retrieved from a six day-old culture using quick filtration. The super-

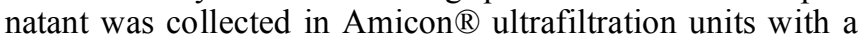
regenerated cellulose membrane for proteins lower than 3.0 $\mathrm{kDa}$.

Activity bioassays were carried out using both fractions. As reported by Berghe and Vlietinck (2005) [34], LB plates were inoculated with a spore suspension of the indicator microorganism (B. subtillis WT or a phytopatogen) $\left(1 \times 10^{6}\right.$ CFU). Wells were made and $100 \mu \mathrm{l}$ of the filtered supernatant was added at different time points during the incubation. Negative (liquid medium) and positive (synthetic peptide $48 \mu \mathrm{M}$ ) controls were also included. Incubation was carried out over $16 \mathrm{~h}$.

\subsection{Peptide Identification}

The use of Tricine-SDS-PAGE $16 \%$ gels with $6 \mathrm{M}$ urea is recommended for the separation of peptides within the 1-100 $\mathrm{kDa}$ range with a good resolution [35], AB-6 stock acrylamide and loading buffer B were used, and $0.2 \mu \mathrm{g}$ of peptide. The electrophoretic run was carried out over $120 \mathrm{~min}$ at 100 Volts and the proteins were stained with Coomassie blue. Gels were scanned and the images were analyzed in a photo document system (Gel Doc $\left.{ }^{\mathrm{TM}} \mathrm{EZ}, \mathrm{Bio}-\mathrm{Rad}\right)$ in order to generate a densitometric profile of the bands.

Experiments were performed in triplicate and repeated three times. The standard deviation was always lower than $2 \%$.

\section{RESULTS}

The simulation of the helix showed that the peptide is stable along $100 \mathrm{~ns}$ at $37^{\circ} \mathrm{C}$. The simulation showed that there exists a region particularly stable between residues 3 to 11 (FKCRRWQWRMKKLEA). The backbone RMSD of all the peptide along the time (calculated each ns) was of $2.49+/-0.52 \AA$ and for those residues 3 to 11 was of $0.62+/-$ $0.4 \AA$. Figure 1 shows the changes that occurred on two snapshots of the simulations.

Based on these results, we assumed that the peptide might conserve the helical conformation along time so the peptide was chemically synthesized and its activity was assessed observing a broad spectrum against phytopathogenic bacteria and fungi (Table 2 ).

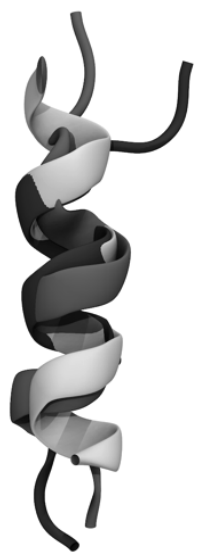

Figure 1. Initial model (C-score of -0.01 and $0.71+-0.11$ of TM.) on white, structure after $77 \mathrm{~ns}$ with the higher backbone RMSD over the residues $3-11$ of $2.1 \AA$ (middle gray) and final structure after $100 \mathrm{~ns}$ with a backbone RMSD over the same residues of 0.58 $\AA$ (darker gray).

Table 2. Activity of the peptide. Growth inhibition percentage (\%) (optical density at $600 \mathrm{~nm}$ ).

\begin{tabular}{|c|c|c|c|}
\hline Microorganism & $\begin{array}{c}\text { Synthetic } \\
\text { peptide }\end{array}$ & $\begin{array}{c}\text { Produced } \\
\text { peptide }\end{array}$ & Taxon \\
\hline \hline Collectotrichum sp. & $5.83 \%$ & $5.36 \%$ & Fungi \\
\hline Fusarium oxysporum & $6.31 \%$ & $5.81 \%$ & Fungi \\
\hline Fusarium solani & $7.00 \%$ & $6.24 \%$ & Fungi \\
\hline Nigrospora oryzae & $57.84 \%$ & $52.21 \%$ & Fungi \\
\hline $\begin{array}{c}\text { Pseudomonas aureofa- } \\
\text { ciens }\end{array}$ & $67.42 \%$ & $62.03 \%$ & Bacteria \\
\hline $\begin{array}{c}\text { Pseudomonas syringae } \\
\text { pv.tomato }\end{array}$ & $19.29 \%$ & $17.75 \%$ & Bacteria \\
\hline Ralstonia solanacearum & $12.48 \%$ & $11.18 \%$ & Bacteria \\
\hline $\begin{array}{c}\text { Xanthomonas axonopo- } \\
\text { dis pv. citri }\end{array}$ & $79.52 \%$ & $73.06 \%$ & Bacteria \\
\hline
\end{tabular}




\subsection{CAP Production System}

By using preferential codons for S. lividans TK24 and taking into account the considerations previously described in the Methods section, an expression cassette was developed as shown in Fig 2.

\section{5' GGATCCGGTTATACCATTACCGTTCGTCCATATGCTGGACAGGCGCCACGGA \\ ACCGCTCCCACCACCCCTGAGCTGCCCGAACGAGCGTGCGGTCACCGCTCACC \\ GGAACGCCACATCCGGAAATCGACCATCCGGATGGCACTCACTCTCCGCACCG \\ GCAAGACTCCTCACCGCAGTCACCAACCGCATCGATCGAAGGAGAGTTCACCA TGCGTCGCACCCTCAAGGCCGTGGGAGCAGCCGCGGCGGCGGCCACCTGCGTC - CTCGCCGCGACGGCAGGCACCGCGCAGGCCGAGGCCTTCAAGTGCCGGCGGTG GCAGTGGCGGATAAGAAGCTGGCCGCTAGAAGCTT 3'}

Figure 2. Expression cassette for S. lividans TK24. Restric-

tion site, promoter, $\square$ Shine-Dalgarno sequence, start codon, $\square$ signal peptide, $\square$ peptide of interest, $\square$ modified amino acid, $\boldsymbol{}_{\text {stop codon. }}$

From the subcloning into pIDT-Smart, this expression cassette was cloned into the pIJ486 vector to finally transform protoplasts of S. lividans TK24. The transformation was verified by colony PCR, using primers complementary to the multiple cloning site within the pIJ486 vector for amplification of the fragments as reported by Van Dessel, 2003 [28].

DNA sequencing was performed using the purified material obtained from the bands in the agarose gel. Results showed $100 \%$ identity between the amplified region and the oligonucleotide sequence of the designed expression cassette.

\subsection{Activity Assays on Bacteria}

Peptide production was evaluated in a Petri dish using the cover bioassay. On the surface of these bioassay dishes, a halo of inhibition was observed, resulting from the secreted peptide by the transformant. It was nuified that no activity was obtained from the parental strain.
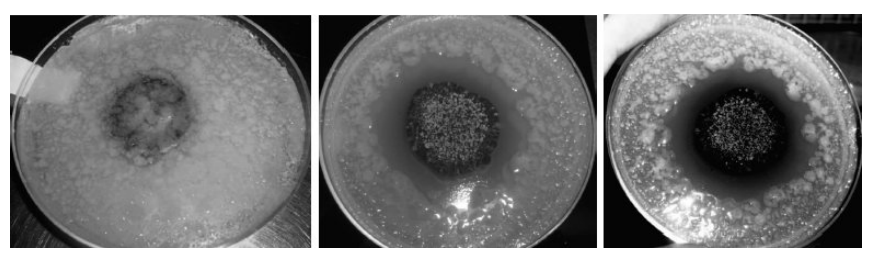

Figure 3. Cover bioassay. Left: Parental strain with $B$. subtilis, Center: Transformant with B. subtilis, Right: Transformant with the Xanthomonas phytopathogen.
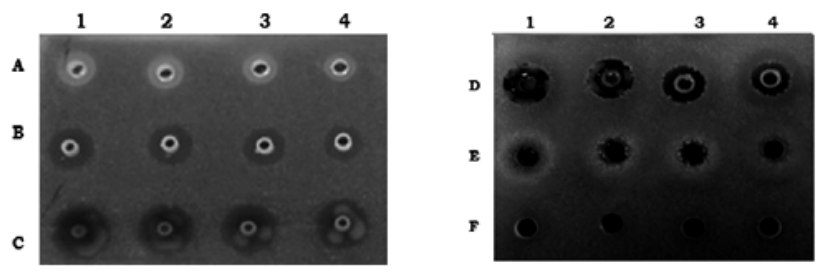

Figure 4. Diffusion bioassay. Line A, Concentration curve of the synthetic peptide $(0.0132,0.0099,0.0066$ and $0.0033 \mathrm{mg} / \mu 1)$; Lines $\mathrm{B}$ and $\mathrm{C}$, supernatant activity after six days of fermentation (200, $180,150,100 \mu 1$ ); Line $\mathrm{D}$, activity of the fraction above $3 \mathrm{kDa}$; Line E, growth of the fraction lower than $3 \mathrm{kDa}$ and Line F, activities of the supernatants from the parental strain.

The results suggest that CAP is actively secreted into the culture medium because of the signal peptide, as previously demonstrated by other studies in which it was secreted through the Sec pathway [31, 32]. In order to verify this, a cell culture fractioning was performed on a six day-old fermentation in which the biomass was removed through quick filtration. The supernatant was collected in Amicon ${ }^{\circledR}$ ultrafiltration units of $3.0 \mathrm{kDa}$, obtaining two fractions: one superior to $3 \mathrm{kDa}$ and another one below this value. Considering that the peptide has an average mass of $3.51 \mathrm{kDa}$, it should be located in the fraction superior to $3.0 \mathrm{kDa}$.

The Figure 4 shows the inhibition of the indicator microorganism with the fraction superior to $3.0 \mathrm{kDa}$. This effect was absent in the fraction lower than $3.0 \mathrm{kDa}$.

Performing different diffusion bioassays, a peptide standard curve was constructed and the quantification of the produced peptide was achieved, obtaining a concentration of $11.6 \mathrm{~g} / 1$.

In addition, the effect of the peptide on the producer microorganism, S. lividans, was also measured. The results showed a slight negative effect on growth in the diffusion bioassay. These results suggest this sensitivity could be the reason why the peptide production stopped in the transformant strain of $S$. lividans.

\subsection{Peptide Identification}

In order to identify the peptide, Tricine-SDS-PAGE gels were prepared for fragment separation through vertical ele trophoresis. The separation range in these gels is $1-100 \mathrm{kDa}$

The acquired images of the Tricine-SDS-PAGE gels were analyzed in a photo documentation system $\left(\mathrm{Gel} \mathrm{Doc}^{\mathrm{TM}}\right.$ EZ Bio-Rad) in order to generate a densitometric profile of the bands. Thus, a second quantification of the produced peptide was carried out, obtaining a result of $11.61 \mathrm{mg} / \mathrm{ml}$. Therefore, the quantification results obtained from the bioassay were corroborated.

\section{DISCUSSION}

During the last years, considerable efforts were made in order to maximize the yield and quality of the proteins produced in heterologous systems [17]. This is even more critical in the case of peptides or proteins that are potentially 


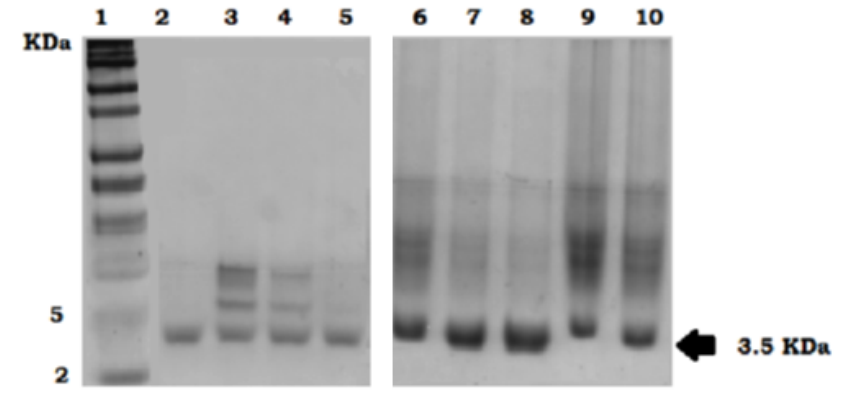

Figure 5. Tricine-SDS-PAGE. 4\% stacking gel, 10\% spacing gel and $16 \%$ separating gel with $6 \mathrm{M}$ urea and stained with Coomassie blue. Lane 1: molecular weight marker; lanes 2- 5: synthetic peptide; lanes 6-10: samples from the transformant growth media.

toxic for the producing organism. Thus, the aim of this study was to achieve the overexpression of a CAP. The strategy employed was the design of a specific system using a selected CAP with known properties regarding its amino acid sequence, size, stoichiometric charge, reliability parameters such as the C-score, structural similarity parameters (RMSD) and topological measurements (TM-score). The presence of hydrophobic and positively-charged amino acids are important for CAP activity and it has been reported that the substitution of a glutamic acid for alanine frequently results in improved activity $[36,37]$. Taking this into account, it was confirmed that by modifying the amino acid sequence, specifically substituting Glu for Ala in the 14th position, results in enhanced toxicity. This offers a reliable and stable model.

Regarding the production strain, (Streptomyces lividans) it does not possess a periplasmic space. Thus, the produced proteins are secreted into the growth medium, simplifying their folding, purification and proper activity. This also contributes to prevent its intracellular accumulation that normally has toxic effects on the host.

During the construction of the expression cassette the use of preferential codons in Streptomyces [30, 38], was considered. The promoter of the parental strain was exchanged for the $S$. venezuelae vsi sequence that, according to previous reports, has displayed a high efficiency [31-33]. The replicative vector pIJ486 was selected, which includes a transcription terminator sequence [39] and resistance to thiostrepton as a selection marker. The Shine-Dalgarno sequence was located [40]. The start codon was ATG in order to provide a correct RNA translation and stability.

Finally, the secretion pathway of the produced peptide was considered. Two of these have been described in Streptomyces sp: the Sec and Tat pathways. In this study, the former was selected for peptide excretion. The proteins in this pathway contain a signal peptide that is eventually removed by a Type I signal peptidase (Spase). These are essential for cell viability and their elimination leads to the accumulation of precursor proteins in cell membranes, and subsequently to cell death $[41,42]$. S. lividans possesses four Type I SPases: $\mathrm{W}, \mathrm{X}, \mathrm{Y}, \mathrm{Z}$ [43-45]. This pathway might be the underlying cause of the system's efficiency regarding CAP secretion, cell death evasion and the prevention of the toxic effect on the host microorganism, in comparison to other expression systems previously reported [7-9, 46].

Regarding the secreted cationic peptide, it displayed a broad-spectrum activity against Gram-positive and Gramnegative bacteria as well as fungi. The effect is variable depending on the affinity of the membrane towards the peptide, its lipid composition and its physicochemical properties. According to several authors, peptide concentration is also an important factor related to its effectiveness when acting on the membrane of the target microorganism [47-51]. The effect was less pronounced on fungi, probably because of the decreased interaction between the peptide and their cell membrane $[12,52,53]$.

Using the described system for CAP production, it is possible to produce efficiently, an interesting metabolite to handle phytopathogens in agriculture at low costs. Additionally, its application could be used in other fields such as medical, food industry, stockbreeding, etc.

\section{CONFLICT OF INTEREST}

Authors thank to the following sources of founding: Marisol Roldán-Tapia, UAM-I, CONACYT (no. 332832); Armando Mejía, UAM-I; Jozef Anné, Rega Institute, KUL; Ana Gisela Reyes, UAM-I; Ulises Carrasco, UAM-I; Cesar Millán-Pacheco, UAM-I; Javier Barrios-González, UAM-I

\section{ACKNOWLEDGEMENTS}

We thank Alejandra Serrato Díaz from Divisional Laboratory of Molecular Biology (UAM) for her technical help. Authors also gratefully acknowledges to the UAM Super Computer Center (UAM-Iztapalapa) Aitzaloa and Yoltla.

\section{REFERENCES}

[1] Yalin Y., Z.T., Da T., Jun Z., Jiarong W., JianhuaW., High-level production of a candidacidal peptide lactoferrampin in Escherichia coli by fusion expression. J. Biotec, 2009. 139(4): p. 326-331.

[2] Marcos et al., M.A., Pérez-Payá E, Misra S, López -García Belén, Identification and Rational Design of Novel Antimicrobial Peptides for Plant Protection. Annu Rev Phytopathol., 2008. 46: p. 273-301.

[3] Verkleij et al., Z.R., Roelofsen B, Comfurius P, Kastelijn D and Van Deenen L., The asymmetric distribution of phospholipids in the human red cell membrane. A combined study using phospholipases and freeze-etch electron microscopy. . Biochim Biophys Acta., 1973. 323: p. 178-193.

[4] Sahl., P.a., The co-evolution of host cationic antimicrobial peptides and microbial resistance. Nat. Rev. Microbiol., 2006. 4: p. 529536.

[5] Yount., Y.a., Mechanisms of antimicrobial peptide action and resistance. Pharmacol Rev., 2003. 55: p. 27-55.

[6] Li., Recombinant production of antimicrobial peptides in Escherichia coli: a review. . Protein expr purif., 2011. 80(2): p. 260267.

[7] Andersons, D.E., A.; Josephson, S.; Hansson, L.; Steiner, H. , Biologically active and amidated cecropin produced in a baculovirus expression system from a fusion construct containing the antibodybinding part of protein A. Biochem J 1991. 280: p. 219-224.

[8] Callaway et al., L.J., Haselbeck B, Baltaian M, Bonnesen SP, Weickmann J, Wilcox G, Lei SP, Modification of the C terminus of cecropin is essential for broad-spectrum antimicrobial activity. Antimicrob Agents Chemother., 1993.37: p. 1614-1619.

[9] Hara, S.Y., M., Production in Escherichia of moricin, a novel type antibacterial peptide from the silkworm, Bombyx mori. . Biochem Biophys Res Commun, , 1996, . 220(3), : p. 664-669. . 
[10] Xu et al., W.F., Peng L, Fang X, Cen P Expression of human betadefensin-2 with multiple joined genes in Escherichia coli. Appl Biochem Biotechnol., 2005. 120(1): p. 1-13.

[11] Lee et al., H.S., Kim SC., Expression of an antimicrobial peptide magainin by a promotor inversion system. J Microbiol Biotechnol., 1998. 8: p. 34-41.

[12] Sharma et al., K.-C.A., White SP, Dhanjal NK, Huang W, Paulhiac C, Friedman EJ, Manjula BN, Kumar R, High-efficiency synthesis of human alpha-endorphin and magainin in the erythrocytes of transgenic mice: a production system for therapeutic peptides. . Proc Natl Acad Sci USA, 1994.91(20): p. 9337-9341.

[13] Lee et al., M.I., Park CB, Kim SC Acidic peptide-mediated expression of the antimicrobial peptide buforin II as tandem repeats in Escherichia coli. Protein Expr Purif. , 1998. 12: p. 53-60.

[14] Fengliang et al., X.X., Liexi Wang, Wenqing Zhang, Dexiang Gu, Expression of recombinant hybrid peptide cecropinA(1-8)- magainin2(1-12) in Pichia pastoris: Purification and characterization. Protein Expr Purif., 2006. 50: p. 147-156.

[15] Piers et al., B.M., Hancock RE Recombinant DNA procedures for producing small antimicrobial cationic peptides in bacteria. Gene, 1993. 134: p. 7-13.

[16] Pimienta et al., F.R., Sánchez JC, Vallín C, Secretion of human interferon alpha $2 b$ by Streptomyces lividans. Appl Microbiol Biotechnol., 2002. 58: p. 189-194.

[17] Anné, J.M., B.; Van Impe, J.; Van Mellaert, L., Recombinant protein production and streptomycetes. J. Biotec., 2012. 158(4): p. 159-167.

[18] Roy, A.K., A.; Zhang, Y. , I-TASSER: a unified platform for automated protein structure and function prediction. Nature Protocols, , 2010, 5((4)): p. 725-738.

[19] Zhang, Y., I-TASSER server for protein 3D structure prediction. . BMC Bioinformatics, , 2008. 9((1)): p. 40 .

[20] Jo, S.K., T.; Iyer, V. G.; Im, W., CHARMM-GUI: a web-based graphical user interface for CHARMM. . Journal of Computational Chemistry, 2008. 29((11)): p. 1859-1865. .

[21] Van Der Spoel, D.L., E.; Hess, B.; Groenhof, G.; Mark, A. E.; Berendsen, H. J. C, GROMACS: fast, flexible, and free. . Journal of Computational Chemistry, 2005. 26((16)): p. 1701-1718.

[22] Abraham, M.J.M., T.; Schulz, R.; Páll, S.; Smith, J. C.; Hess, B.; Lindahl, E, GROMACS: High performance molecular simulations through multi-level parallelism from laptops to supercomputers. SoftwareX, 2015. 1-2: p. 19-25.

[23] MacKerell, J., A. D.; Banavali, N.; Foloppe, N. , Development and current status of the CHARMM force field for nucleic acids. Biopolymers, 2001. 56: p. 257-65.

[24] Hopwood et al., B.M., Chater KF, Kieser T, Bruton CJ, Kieser HM, Lydiate DJ, Smith CP, Ward JM, Schrempf H., Genetic manipulation of Streptomyces: A laboratory manual. 1985, John Innes Foundation.: Norwich, CT.

[25] Sambrook et al., F.E., Maniatis T Molecular cloning: A laboratory manual in Cold Spring Harbor Laboratory. 1989: Cold Spring Harbor, N.Y.

[26] Grant., E.coli Genotypes. 1990.

[27] Kieser et al., T., Bib, M., Buttner, M., Chater, K., Hopwood, D.,, Practical Streptomyces Genetics. , ed. T.J.I. Foundation. 2000, Norwich.

[28] Van Dessel et al., V.M.L., Geukens N, Anné J, Improved PCRbased method for the direct screening of Streptomyces transformants J Microbiol Methods, 2003. 53(3): p. 401-403.

[29] Stevens et al., S.B., Klapes NA, Klaenhammer TR, Nisin treatment for inactivation of Salmonella species and other gram-negative bacteria. App Environ Microbiol., 1991. 57: p. 3613-3615.

[30] Wright, F.B., MJ., Codon usage in the $G+C$-rich Streptomyces genome. . Gene, , 1992, . 113, : p. 55-65.

[31] Lammertyn et al., D.S., Schacht S, Van Mellaert L, Anné J Influence of charge variation in the Streptomyces venezuelae alpha- amylase signal peptide on heterologous protein production by Streptomyces lividans. Appl Microbiol Biotechnol., 1998. 49(424430).

[32] Lammertyn et al., V.M.L., Schacht S, Dillen C, Sablon E, Van Broekhoven A, Evaluation of a novel subtilisin inhibitor gene and mutant derivatives for the expression and secretion of mouse tumor necrosis factor alpha by Streptomyces lividans. Appl Environ Microbiol., 1997. 63: p. 1808-1813.

[33] Van Mellaert et al., L.E., Schacht S, Proost P, Van Damme J, Wroblowski B, Molecular characterization of a novel subtilisin inhibitor protein produced by Streptomyces venezuelae CBS762.70. DNA Seq., 1998. 9: p. 19-30.

[34] Bergher, P., Antiviral botanicals in herbal medicine. Med. Herb., 2005. 14: p. 1-12.

[35] Schägger., Protocol: Tricine-SDS-PAGE. Nat Protoc., 2006. 1: p. $16-22$

[36] Strøm et al., S.W., Svendsen JS, Rekdal Ø, Increased antibacterial activity of 15-residue murine lactoferricin derivatives. J Pept Res., 2001. 57: p. 127-139.

[37] Strøm et al., S.J., Rekdal Ø, Antibacterial activity of 15 -residue lactoferricin derivatives. . J Pept Res., 2000. 56: p. 265-274.

[38] Ueda et al., T.S., Nishiyama KI, Kumagai I, Miura KI Effect of a rare leucine codon, TTA, on expression of a foreign gene in Streptomyces lividans. Biochim Biophys Acta., 1993. 1172: p. 262-266.

[39] Pulido, D.J., A. , Optimization of gene expression in Streptomyces lividans by a transcription terminator. Nucleic Acids Res, , 1987, . 15(10), : p. 4227-4240. .

[40] Strohl., Compilation and analysis of DNA sequences associated with apparent streptomycete promoters. . Nucl Acids Res., 1992. 20(5): p. 961-974.

[41] Dalbey et al., L.M., Bron S y van Dijl JM The chemistry and enzymology of the type I signal peptidases. Protein Sci. , 1997. 6: p. 1129-1138.

[42] Koshland et al., S.R., Botstein D Diverse effects of mutations in the signal sequence on the secretion of beta-lactamase in Salmonella typhimurium. Cell, 1982. 30: p. 903-914.

[43] Parro, V.M., R.P., A new signal peptidase gene from Streptomyces lividans TK21. DNA Seq, , 1998, .9, : p. 71-77.

[44] Parro et al., S.S., Anne J, Mellado RP Four genes encoding different type I signal peptidases are organized in a cluster in Streptomyces lividans TK21. Microbiology, 1999. 145: p. 2255-2263.

[45] Schacht et al., V.M.L., Lammertyn E, Tjalsma H, van Dijl JM, Bron S., The Sip (Sli) gene of Streptomyces lividans TK24 specifies an unusual signal peptidase with a putative C-terminal transmembrane anchor. . DNA Seq., 1998. 9: p. 79-88.

[46] Parachin et al., M.K., Viana AA, Dias SC, Franco OL. , Expression systems for heterologous production of antimicrobial peptides. Peptides, 2012. 38(2): p. 446-456.

[47] Hwang, Action of antimicrobial peptides: two-state model. Biochemistry 2000. 39: p. 1-6.

[48] Matsuzaki, Magainins as paradigm for the mode of action of pore forming polypeptides. Biochim Biophys Acta, 1998. 1376.

[49] Matsuzaki et al., S.K., Fshibe N Relation ship of membrane curvature to the formation of pores by magainin 2. Biochemistry, 1998. 37: p. 11856-11863.

[50] Nes, N.-M.a., Ribosomally synthesized antimicrobial peptides: Their function, structure, biogenesis and mechanism of action. Arch Microbiol., 1997. 167(2-3): p. 67-77.

[51] Shai, Mode of action of membrane active antimicrobial peptides. Pept Sci., 2002. 66(4): p. 236-248.

[52] Hancock, R.E.W., Lehrer, R. , Cationic peptides: a new source of antibiotics. . Trends in Biotechnol, , 1998, . 16, : p. 82-88.

[53] Nakashima et al., M.Y.a.T.T., Actinomycetes as host cells for production of recombinant proteins. Microb cell Fact, 2005. 4(1): p. 7. 